\title{
REKONSTRUKSI POLA PIKIR HAKIM DALAM MEMUTUSKAN PERKARA KORUPSI BERBASIS HUKUM PROGRESIF*
}

\author{
M. Syamsudin \\ Fakultas Hukum Universitas Islam Indonesia Yogjakarta \\ E-mail: m.syamsudin@fh.uii.ac.id;
}

\begin{abstract}
This study aims to reveal and then reconstruct the mindset of judges in deciding corruption cases based Progressive Law. Academic question posed is whether the condition of existing as the mindset of judges in deciding cases of corruption and how to build a new construction mindset of judges based on the principles of Progressive Law. This research is classified in the tradition of nondoctrinal legal research with sosiolegal approach. Data collected by interview, observation and document study and then analyzed following the interactive model of Mattew B. Miles and A. Michael Haberman. The results of study indicate the need for new construction mindset of judges based progressive law. This is based on the empirical reality that the judge handling the case of corruption by many experienced deterioration and failure to bring the law in a fair, useful and protect the interests of society. The mindset of the judge who figured positivistic needs to be reorganized under the new progressive mindset in deciding the various legal problems that emerged recently that the more complex and complicated, especially in deciding the case of corruption. Judges at all levels of education and environmental justice needs to be improved for the judge able to resolve various legal issues properly, fairly and wisely.
\end{abstract}

Key words: reconstruction, the mindset of judges, corruption cases, progressive law

\begin{abstract}
Abstrak
Studi ini bertujuan untuk mengungkap dan kemudian merekonstruksi pola pikir hakim dalam memutuskan perkara korupsi berbasis Hukum Progresif. Pertanyaan akademik yang diajukan adalah seperti apakah kondisi existing pola pikir hakim dalam memutuskan perkara korupsi dan bagaimanakah membangun konstruksi baru pola pikir hakim berdasarkan prinsip-prinsip Hukum Progresif. Penelitian ini tergolong dalam tradisi penelitian hukum non-doktrinal dengan pendekatan sosiolegal. Data dihimpun dengan wawancara, observasi dan studi dokumen dan kemudian dianalisis mengikuti model interaktif dari Mattew B.Miles dan A.Michael Haberman. Validasi data dilakukan dengan triangulasi sumber dan metode. Hasil pembahasan menunjukkan perlunya konstruksi baru pola pikir hakim berbasis hukum progresif. Hal ini didasarkan pada realitas empirik bahwa penanganan perkara korupsi oleh hakim banyak mengalami kemerosotan dan kegagalan untuk menghadirkan hukum yang adil, bermanfaat dan melindungi kepentingan masyarakat. Pola pikir hakim yang bercorak positivistik perlu ditata ulang berdasarkan pola pikir baru yang progresif dalam memutuskan berbagai problem hukum yang muncul akhir-akhir ini yang semakin kompleks dan rumit, terutama dalam memutuskan perkara korupsi. Pendidikan hakim di semua tingkatan dan lingkungan pengadilan perlu ditingkatkan agar hakim mampu memecahkan berbagai permasalahan hukum secara tepat, adil dan bijaksana. Muatan hukum progresif perlu dielaborasikan dalam pendidikan calon hakim dan isntitusi pendidikan hukum pada umumnya
\end{abstract}

Kata kunci: rekonstruksi, pola pikir hakim, perkara korupsi, hukum progresif

\section{Pendahluan}

Artikel ini merupakan bagian kedua dari penelitian multi years Hibah Bersaing Dikti ta-

- Artikel ini merupakan hasil penelitian multi years Hibah Bersaing yang dibiayai oleh DP2M Dikti Kementrian Pendidikan Nasional RI, anggaran tahun 2010. hun 2010 yang berjudul "Membangun Budaya Hukum Hakim dalam Proses Memutuskan Perkara Korupsi Berbasis Hukum Progresif". Hasil temuan penelitian pada tahap pertama menunjukkan adanya dua kecenderungan pola pikir 
hakim dalam menangani perkara korupsi, yaitu pertama pola pikir hakim yang bercorak positivistik dan kedua pola pikir hakim yang bercorak non-positivistik. Pola pikir hakim dengan corak yang pertama sangat menekankan pada ukuran-ukuran formal teks aturan (aturan sentris) dalam menggali kebenaran hukum, sedangkan pola pikir dengan corak yang kedua mengelaborasikan teks aturan hukum dengan konteks sosiolegal ${ }^{1}$ dalam menggali kebenaran hukum. ${ }^{2}$

Kecenderungan pola pikir hakim tersebut tidak dapat dilepaskan dari sistem pengetahuan yang dimiliki hakim dan kemudian dari sistem pengetahuan yang dimilikinya itu menentukan corak atau karakter pemikirannya dalam memutuskan suatu perkara di pengadilan. Dalam praktik terdapat kecenderungan umum (mainstream) para hakim mengikuti pola berpikir legal positivism dan jarang sekali ditemukan hakim yang mengikuti cara berpikir non-positivistik dalam memutuskan perkara. Corak berpikir positivistik ini sebenarnya lahir dari paham hukum yang diikuti hakim selama ini yaitu paham positivisme hukum. Paham positivisme hukum ini melahirkan pola pikir hakim yang bercorak positivistik dalam memutuskan perkara. ${ }^{3}$

Pola pikir yang bercorak positivistik dan yang non-positivistik pada tataran praksisnya melahirkan kecenderungan hakim yang berbeda dalam melakukan pemaknaan atau penafsiran hukum dalam memutuskan perkara korupsi.

Konteks sosiolegal disini dimaksudkan bahwa dalam memahami hukum para pengkaji tersebut berupaya mengaitkan dengan faktor-faktor sosial, budaya dan sebaginya yang bersifat interdisipliner. Baca Sulistyowati Irianto \& Shidarta (ed), 2009, Metode Penelitian Hukum Konstelasi dan Refleksi. Jakarta: Yayasan Obor Indonesia. hlm. 173-175; Werner Menski, 2006. Comparative Law in a Global Context, The Legal Systems of Asia and Africa. Second Edition. New York: Cambridge University Press. hlm. 161-162.

2 M.Syamsudin, Pemaknaan Hakim tentang Korupsi dan Implikasinya terhadap Putusan: Studi Perspektif Hermeneutika Hukum", J urnal Mimbar Hukum FH UGM, Vol.22. No.4.Oktober 2010. hlm. 510. Bandingkan dengan Al. Wisnubroto, "Upaya Mengembalikan Kemandirian Hakim Melalui Pemahaman Realitas Sosialnya", J urnal Hukum Pro Justitia, Tahun XX No. 1 Januari 2003, hlm. 9-23.

3 M. Syamsudin, op.cit. hlm. 511. Bandingkan dengan tulisan Faisal A. Rani, "Hakim Sebagai "Quasi Legislator", J urnal Hukum Pro J usitia, Tahun Ke 20 No. 2 April 2002, hlm. 24-35.
Hasil penelitian menemukan dua tipe hakim dalam memaknai korupsi yaitu "tipe hakim tekstual" dan "tipe hakim kontekstual". Pemaknaan tekstual yaitu penafsiran sempit yang hanya mengacu pada teks undang-undang yang berlaku, sedangkan pemaknaan kontekstual yaitu penafsiran luas yang selain mengacu pada bunyi teks hukum juga mengaitkan dan memperhatikan faktor-faktor sosiolegal yang ada. Dalam praktik, pola pikir hakim dengan tipologi pemaknaan tektual masih mendominasi paradigma hakim dalam menafsirkan ketentuan perundang-undangan korupsi. Implikasinya hakim menjadi sulit atau dapat dikatakan gagal membuktikan unsur-unsur tindak pidana korupsi, sehingga banyak melahirkan putusan bebas. ${ }^{4}$

Hasil penelitian juga mengungkapkan bahwa orientasi hakim dalam menjalankan hukum juga sangat menentukan keberhasilan hakim dalam memutuskan perkara korupsi di pengadilan. Ada tiga tipologi orientasi hakim dalam menjalankan hukum yaitu ada yang berorientasi materialis disebut tipe hakim materialis, ada yang berorientasi pragmatis di sebut hakim pragmatis, dan ada yang berorientasi idealis disebut hakim idealis. Hakim materialis adalah hakim yang suka menjadikan kasus sebagai sumber komoditi untuk mendapatkan keuntungan materi. Hakim pragmatis adalah hakim yang selalu mengikuti arah angin dan situasi yang menguntungkan dirinya baik secara materiil maupun immateriil. Hakim idealis adalah hakim yang mempunyai idealisme untuk mewujudkan tujuan hukum yaitu keadilan dan selalu menolak pemberian apapun dari pihak-pihak yang berkepentingan.

Dalam praktik terekam pula bahwa aktivitas hakim dalam menangani suatu perkara,

M. Syamsudin, "Kecenderungan Paradigma Berpikir Hakim dalam Memutuskan Korupsi", Jurnal Media Hukum FH UMY, Vo.15 No.2. Des 2008. hlm.188; Bandingkan dengan Koesnoe yang membagi dua faham hukum dalam menafsirkan suatu ketentuan hukum, yaitu faham juridisme positivistis dan juridisme idealistis. Baca lebih lanjut pada Moh. Koesnoe. "Apa Artinya Yuridis itu? Kajian Ukuran dan Persoalannya Dewasa ini" Varia Peradilan. No. 118 Edisi Juli 1995. $\mathrm{hlm}$. 35. Bandingkan pula dengan Adolf Heuken, "TeIadan Hakim yang Bij aksana, Tegas, dan Memperhatikan Situasi", Jurnal Keadilan, Vol. 2 No. 1, Tahun 2002, hlm. 32-33. 
banyak sekali godaannya terutama godaan yang bersifat material. ${ }^{5}$ Dalam konteks ini, penanganan suatu perkara dapat dimaknai sebagai sumber komoditi untuk mendapatkan keuntungan secara material. Singkat kata, aktivitas hakim dalam memutuskan perkara sangat rentan dengan praktik-praktik koruptif (baca: suap menyuap). ${ }^{6}$

\section{Permasalahan}

Berdasarkan hasil-hasil temuan penelitian seperti yang telah dipaparkan tersebut, dimunculkan pertanyaan akademik bagaimanakah membangun konstruksi baru pola pikir hakim yang progresif dalam memutuskan perkara korupsi sehingga mampu mewujudkan putusan yang adil, bermanfaat dan melindungi hak-hak dan kepentingan masyarakat?

\section{Metode Penelitian}

Penelitian ini tergolong dalam tradisi penelitian hukum nondoktrinal dengan pendekatan sosiolegal. Subjek penelitian adalah hakim yang didukung oleh informan dan nara sumber. Data dihimpun dengan metode wawancara, observasi dan studi dokumen. Data dianalisis mengikuti model interaktif, yang terdiri dari kegiatan pengumpulan data, reduksi data, penyajian data, dan penarikan simpulan/verifikasi. Untuk menjamin validitas, objektivitas dan keterandalan data ditempuh pemeriksaan triangulasi. Dalam penelitian ini digunakan triangulasi sumber dan metode. Triangulasi sumber dan metode dilakukan dengan cara melakukan cek silang antara sumber data dan metode yang satu dengan data lainya, baik yang diperoleh lewat metode wawancara, observasi, studi dokumentasi/pustaka maupun catatan lapangan.

\section{Pembahasan}

Uraian pembahasan ini pada intinya hendak menganalisis tentang pola pikir hakim didasarkan pada prinsip-prinsip hukum progresif. Tujuan analisis diorientasikan untuk mem-

Wawancara dengan kode AA. Hakim Agung RI.

Wawancara dengan kode SS. Mantan hakim di PN Jogjakarta. bangun konstruksi baru sebagai hasil dari rekonstruksi atas kondisi existing hasil penelitian. Rekonstruksi sendiri dimaknai sebagai proses membangun kembali atau menciptakan kembali atau melakukan pengorganisasian kembali atas sesuatu. ${ }^{7}$ Sesuatu yang dimaksudkan adalah pola pikir hakim. Jadi, rekonstruksi pola pikir hakim berbasis hukum progresif dimaksudkan proses membangun kembali pola pikir hakim dalam menangani suatu perkara (korupsi) yang didasarkan pada asumsi-asumsi, konsep-konsep dan prinsip-prinsip hukum progresif dalam rangka mewujudkan nilai-nilai hukum dalam memutuskan perkara. ${ }^{8}$ Nilai-nilai hukum itu tersimpan dan juga tersimbolkan dalam judul (irah-irah) di setiap putusan hakim yaitu: "DEMI KEADILAN BERDASARKAN KETUHANAN YANG MAHA ESA". 9

Pentingnya suatu konstruksi baru pola pikir hakim bertolak dari kondisi existing (hasil studi) atas penanganan perkara (korupsi) oleh hakim di pengadilan saat ini banyak mengalami kemerosotan atau dapat dibilang kegagalan untuk menghadirkan hukum yang adil, bermanfaat dan melindungi kepentingan masyarakat (social justice). Pola pikir hakim yang bercorak positivistik perlu dibangun kembali (ditata ulang) berdasarkan pola pikir baru yang progresif dalam menyelesaikan problem hukum yang muncul akhir-akhir ini yang semakin kom-

Baca Bryan A.Garner, 1999, Black' Law Dictionary. Edisi ke-7. ST.Paul Minn: West Group. hlm. 1278. Reconstruction is the act or process of rebuilding, recreating, or reorganizing something.

8 Bandingkan dengan rumusan nilai-nilai hukum oleh Radbruch yaitu niali keadilan, kepastian, dan kegunaan. Gustav Radbruch dalam The Legal Philosophies of Lask, Radbruch, and Dabin. Cambridge. Massachusetts, Harvard University Press. hlm.107-108. Bandingkan dengan tulisan Ridwan, "Memunculkan Karakter Hukum Progresif dari Asas-asas Umum Pemerintahan yang Baik Solusi Pencarian dan penemuan Keadilan Substantif", Jurnal Hukum Pro J ustitia, Vol. 27 No. 1 April 2009, hlm. 6780.

9 Judul (irah-irah) tersebut harus dicantumkan di setiap putusan hakim dan jika tidak dicantumkan berdasarkan Pasal 197 ayat (1) KUHAP putusan batal demi hukum. Lihat juga Pasal 2 ayat (1) UU No. 48 tahun 2009 tentang Kekuasaan Kehakiman: peradilan dilakukan "DEMI KEADILAN BERDASARKAN KETUHANAN YANG MAHA ESA". J uga lihat Pasal 8 ayat (3) UU Kejaksaan No.16 Tahun 2004: Demi keadilan dan kebenaran berdasarkan Ketuhanan Yang Maha Esa, jaksa melakukan penuntutan dengan keyakinan berdasarkan alat bukti yang sah. 
pleks dan rumit, terutama dalam memecahkan masalah korupsi.

Pola pikir hakim yang progresif diperlukan karena berdasarkan hasil studi ditemukan adanya kesulitan atau dapat dikatakan kegagalan hakim dalam menangani korupsi disebabkan karena hakim masih mengikuti pola pikir yang bercorak positivistik. ${ }^{10}$ Cara berpikir ini masih diikuti secara dominan oleh para hakim di pengadilan. Dalam pandangan positivisme hukum, hukum dikonsepkan sebagai lawyer's law, dalam arti hukum itu identik dengan undangundang, proses hukum harus berjalan menurut prinsip 'aturan dan logika' (rules and logic), dan undang-undanglah yang dianggap paling mampu menertibkan masyarakat. Pandangan ini melihat hukum sebagai suatu institusi pengaturan yang linier, mekanik, dan diterministik terutama untuk kepentingan profesi hukum sendiri. Paham ini melihat hukum sebagai sesuatu yang rasional, logis, penuh kerapian dan keteraturan. Tegasnya hukum adalah sebuah order yang diterapkan kepada manusia dan karena manusia harus tunduk kepadanya. ${ }^{11}$

Paham ini menempatkan hukum tidak untuk manusia melainkan manusia dipaksa menyesuaikan dengan format undang-undang dan prosedur teknis. Institusi hukum yang formalistik, birokratis, sentralistik dibangun untuk melayani hukum yang demikian. Sudah barang tentu keadaan ini hanya dapat diakses oleh mereka yang memiliki kelebihan ekonomi, politik, dan mampu akses untuk mengikuti segala tata cara/ prosedur yang ditetapkan. ${ }^{12}$

10 Paham ini lahir dari basis filsafat hukum modern yang merupakan produk sosial, ekonomi, dan kultur barat, khususnya Eropa, yang memiliki tipe liberal, kapitalistik, dan individualistik. Menurut Rahardjo cara berhukum dengan tipe seperti itu sudah ditanamkan kepada mahasiswa sejak duduk di bangku kuliah di fakultas hukum di Indonesia. Baca Satjipto Rahardjo, 2009. Hukum Progresif sebuah Sintesa Hukum Indonesia. Jogjakarta: Genta Publishing.hlm.141. Lihat juga Satjipto Rahardjo, "Hukum Progresif: Hukum Yang Membebaskan", Jurnal Hukum Progresif, Vol. 1 No. 1, April 2005.

11 Satjipto Rahardjo, "Konstitusional dari Dua Sudut Pandang", Kompas, 7 September 1998, hlm. 4.

12 Esmi Warassih, "Hukum Progresif J awaban Alternatif Menuju Pembangunan Hukum Indonesia Menghadapi Mafia Peradilan", Makalah disampaikan pada Seminar Nasional Menembus Kebuntuan Legal Formal Menuju Pembangunan Hukum dengan Pendekatan Hukum progresif, FH Undip 19 Desember 2009. hlm. 3.
Paham positivisme hukum menjadikan aturan sebagai acuan dan sumber satu-satunya bagi hakim dalam mengadili korupsi. Hakim hanyalah diposisikan sebagai corong undangundang dan hanya boleh menerapkan undangundang secara mekanis dan prosedural. Aturan hukum ditempatkan sebagai pusat dan tujuan dalam dirinya sendiri, tanpa memperhatikan dimensi-dimensi lain di luar aturan. Kejujuran dan kearifan dalam menjalankan hukum, justru terabaikan. Akibatnya, kepekaan, empati, serta dedikasi untuk menghadirkan keadilan dan kebenaran tertinggal jauh di belakang. Kebenaran dan keadilan hanya menjadi persoalan legalformal belaka. Cara berpikir ini sangat mengutamakan nilai kepastian hukum dibandingkan dengan nilai keadilan dan kegunaan. Cara berpikirnya lazimnya bersifat deduktif dalam menemukan kebenaran hukum dengan mengutamakan logika formal (silogisme). ${ }^{13}$

Karakter teknisitas tersebut menggiring hukum pada posisi yang siap "direkayasa". Bagi orang yang menguasai hukum dan teknik hukum yang tinggi, akan tetapi rendah moralitasnya, akan dapat memanfaatkan hukum dengan sebaik-baiknya untuk memenangkan kasus yang sedang ditanganinya. Bahkan jika memiliki kecenderungan senang berkolaborasi dengan pihak yang melakukan kejahatan, maka baginya hukum sewaktu-waktu dapat diubah sebagai alat kejahatan (law as a tool of crime). Perbuatan jahat dengan hukum sebagai alatnya merupakan kejahatan yang sempurna, sulit dilacak, karena diselubungi hukum dan berada di dalam hukum. ${ }^{14}$

Kuatnya cara berpikir legal positivism di kalangan hakim Indonesia menjadi penyebab utama koruptor terlepas dari jeratan hukum. Berbagai praktik korupsi dilakukan begitu massif dan telanjang, tetapi semua itu sulit ditindak, hal ini disebabkan karena aparat penegak hukum, terutama hakim hanya berpegang pada bunyi teks peraturan hukum secara eksplisit

13 Baca "Hukum itu Manusia, bukan Mesin" dalam Satjipto Rahardj 0, 2007, "Biarkan Hukum Mengalir Catatan Kritis tentang Pergulatan Manusia dan Hukum", J akarta: Kompas. hlm. 91.

14 Tb. Ronny R Nitibaskara, "Hukum sebagai Alat Kejahatan", Kompas, 16 Oktober, 2000. hlm. 4. 
dan sempit serta tidak berupaya mencari makna dalam menafsirkan aturan hukum itu secara lebih luas atau progresif. Di sisi lain, pengalaman selama ini menunjukkan bahwa pemberantasan korupsi tidak jarang justru dihambat atau dikalahkan oleh penggunaan asas dan doktrin tertentu yang masuk dalam ranah ilmu dan teori hukum. Dalam praktik apa yang dilakukan oleh aparat penegak hukum (polisi, jaksa, advokat, hakim) sangat ditentukan oleh mindset atau paradigma yang ada di kepala-kepala mereka. Paradigma menentukan bagaimana mereka membaca dan memaknai hukum yang digunakan. Peraturan yang sama dapat dibaca secara berbeda oleh orang-orang dengan paradigma yang berbeda. ${ }^{15}$

Problem yang bersifat paradigmatis tersebut sungguh tidak mamadai jika hanya diselesaikan melalui proses hukum yang sederhana dan biasa-biasa saja. Oleh karena itu perlu dicarikan alternatif paradigma baru yang mampu menyelesaikan permasalahan tersebut secara memadai. Dengan kata lain diperlukan perubahan paradigma dari paradigma legal positivism ke paradigma progresif. Di sinilah relevansi paradigma Hukum Progresif ditawarkan.

Dalam hal ini, Wignyosoebroto menyarankan agar paradigma kerja hakim di negerinegeri berkembang yang berkultur majemuk seperti Indonesia sudah waktunya berubah dan diubah. Hakim bukan lagi sebatas bereksistensi sebagai mulut yang membunyikan kalimat-kalimat undang-undang (le juge est uniquenment la bouche qui prononce le mots de lois). Hakim juga bukan piranti yang dirancang untuk berlogika dan bekerja secara mekanik, melainkan manusia seutuhnya yang punya kepekaan pada inwal kemanusiaan dan kepedulian sosial. Kalaupun hakim itu harus membaca bunyi katakata yang tertera secara tekstual di buku undang-undang, diapun harus pula belajar dan pandai membuat interpretasi yang tidak harfiah (konotatif), agar mampu mengungkap normanorma sosial yang secara kontekstual melatari

15 Satjipto Rahardjo, 2009. Hukum Progresif sebuah Sintesa Hukum Indonesia. J ogjakarta: Genta Publishing, hlm. 137-138. setiap preskripsi undang-undang. Hakim modern yang terdidik untuk melayani kebutuhan hukum masyarakat yang berkultur majemuk, bukanlah kepanjangan tangan badan legislatif. Hakim yang bertugas di daerah-daerah amat diharapkan dapat memainkan peran sebagai agen yang mampu mengantar hukum undangundang yang diproduksi di pusat ditransformasi ke dalam suatu ekspresi kearifan dan keadilan yang bisa diterima oleh warga masyarakat setempat. ${ }^{16}$

Hukum progresif mencoba membogkar cara-cara berhukum yang telah mengakar tersebut dengan kata kunci hukum untuk manusia bukan sebaliknya manusia dipaksa-paksa untuk tunduk pada hukum. Hukum progresif adalah hukum yang membebaskan, hukum yang membahagiakan, hukum yang memuat moral kemanusiaan, dan hukum yang merupakan sebuah proses yang tidak pernah final. Hukum progresif bukan sekedar menerapkan aturan dan hanya untuk memenuhi prosedur melainkan hukum yang harus dilihat sebagai persoalan manusia secara utuh. Hukum progresif adalah hukum yang diperlukan untuk manusia baik dalam aksiinteraksi dengan sesama manusia, maupun manusia dengan alam semesta yaitu lingkungan sosial dan alam sekitarnya. Hukum progresif adalah hukum yang pada hakikatnya mengatur perilaku manusia melalui norma-norma hukum yang diciptakan yang lebih mengutamakan keadilan dan kebahagiaan yang hakiki bagi kehidupan. ${ }^{17}$

Agenda perubahan paradigma meliputi perubahan asumsi dasar atau asumsi filosofisteoretis yang dijadikan sumber nilai, kerangka pikir, orientasi dasar, asas, tolak ukur, parameter, serta arah dan tujuan dari suatu per-

16 Soetandyo Wignyosoebroto, 2010, "Mempersoalkan Keadilan dalam Amar Putusan Hakim" dalam Wajah Hakim dalam Putusan, Studi atas Putusan Hakim Berdimensi Hak Asasi Manusia. Yogyakarta: PUSHAM UII. hlm. 141142. Lihat juga Niken Savitri, "Tugas Hakim dan Penafsiran Atas KUHP", J urnal Hukum Pro J utitia, Vol. 25 No. 4 Oktober 2007, hlm. 339-350.

17 Satjipto Rahardjo, op.cit. Lihat juga Suadamara Ananda, "Hukum dan Moralitas", Jurnal Hukum Pro J ustitia, Vol. 24 No. 3 Juli 2006, hlm. 301-307; dan Frans H. Winata, "Pencapaian Supremasi Hukum yang Beretika dan Bermoral", Jurnal Hukum Pro Justitia, Tahun XX No. 1 J anuari 2003, hlm. 3-8. 
kembangan, perubahan dan proses dalam bidang tertentu, termasuk dalam pembangunan, gerakan reformasi maupun dalam proses pendidikan. Dengan demikian, paradigma menempati posisi dan fungsi yang strategis dalam setiap proses kegiatan, termasuk kegiatan penegakan hukum. Suatu perencanaan, proses pelaksanaan, dan hasil-hasilnya dapat diukur dengan paradigma tertentu yang diyakini kebenarannya. ${ }^{18}$

Paradigma di sini dimaksudkan sebagai pola atau kerangka berpikir hakim dalam menangani perkara. ${ }^{19}$ Kerangka berpikir tersebut didasarkan pada penalaran hakim dalam mengkonstruksi putusan atas suatu kasus konkrit. Penalaran hukum merupakan kegiatan berpikir problematis tersistematisasi dari subjek hukum (manusia, hakim tambahan penulis) sebagai makhluk individu dan sosial di dalam lingkungan kebudayaanya. Disebut problematis karena penalaran hukum merupakan penalaran praktis sebagai konsekuensi dari karakter keilmuan hukum sendiri (sebagai ilmu praktis) yang diabdikan untuk mencari putusan bagi penyelesaian kasus-kasus konkrit. Disebut tersistematisasi karena argumentasi dan putusaan yang dihasilkan harus ditempatkan dalam kerangka hukum sebagai sistem (tatanan). ${ }^{20}$

Dalam kegitan penalaran hukum itu terkait dengan subjek dan objek penalaran yang mengandung 3 (tiga) dimensi, yakni ontologis, aksiologis dan epistemologis. Pertama, dimensi

18 Sugito dkk, 2002, Pendidikan Pancasila. Semarang: UPT MKU UNNES, hlm. 178. Bandingkan dengan Dodo SDW, "Asas Negara Hukum Menurut Paham Pancasila", J urnal Keadilan, Vol. 2 No. 1, Tahun 2002, hlm. 34-40.

19 Makna paradigma meliputi: model dalam teori ilmu pengetahuan, kerangka berpikir, daftar semua bentukan dari sebuah kata yang memperlihatkan konjungsi dan deklinasi kata tersebut. Baca Erlyn Indarti, 2010, Diskresi dan Paradigma Sebuah Telaah Filsafat Hukum, Pidato Pengukuhan Jabatan Guru Besar dalam Flsafat Hukum pada FH Undip. hlm.13-14. Lihat juga Indarti, Erlyn. "Legal Constructivism: Paradigma Baru Pendidikan Dalam Rangka Pembangunan Masyarakat Madani", dalam Majalah IImiah Masalah-Masalah Hukum, Vol. XXX, No. 3, Juli - September 2001, hlm. 139-154 dan Suparlan, Parsudi, "Paradigma Naturalistik dalam Penelitian Pendidikan: Pendekatan Kualitatif dan Penggunaannya", Majalah Antropologi Indonesia No. 53, Vol. 21 - 1997, diterbitka oleh FISIP UI J akarta.

20 Shidarta, 2006, "Filosofi Penalaran Hukum Hakim Konstitusi dalam Masa Transisi Konstitusionalitas". Jurnal Hukum J entera, Edisi 11-tahun III, J anuari-Maret 2006. hlm. 6. ontologis yakni terkait dengan hakikat hukum yang ditetapkan, apakah hukum dimaknai sebagai asas keadilan dan kebenaran, atau hukum sebagai norma hukum positif dalam sistem perundang-undangan, atau hukum sebagai perilaku sosial dalam skala makro dan mikro, dan seterusnya. Kedua dimensi aksiologis, yakni tujuan yang ingin dicapai oleh hukum, yaitu apakah keadilan, kepastian hukum, dan kemanfaatan (gerechtigkeit, rechtssicherheit, und zweckmaaigkeit) atau ketiga-tiganya. Ketiga, dimensi epistemologis yaitu tentang metode atau pendekatan yang digunakan si subjek dalam berhubungan dengan objek telaahnya. Dalam konteks epistemologi ini, penalaran hukum tidak hanya menggunakan rasio sebagai satusatunya modalitas yang dipakai si subjek dalam mendekati objek. Ada modalitas lain di luar rasio, seperti indera dan intuisi. Kenyataannya bahwa para subjek itu tidak sepenuhnya mahluk rasional, tapi juga makhluk etis dan politis. $^{21}$

Berpikir rasional dalam penalaran hukum memang sangat diperlukan, tetapi jelas bukan satu-satunya modalitas penalaran hukum. Hampir seluruh kasus yang dihadapi hakim berstruktur sangat kompleks, sehingga akhirnya penalaran hukum juga harus bersinggungan dengan moral reasoning. Ini merupakan keunikan penalaran hukum. Jika penalaran hukum hanya dibatasi pada aktivitas rasional seperti dikenal dalam ilmu-ilmu pasti, maka konsekuensinya adalah fungsi utama hakim tidak lain sekedar sebagai penerap hukum (law enforcer), menafikan yang lain sebagai pencipta hukum (law creator; law maker). Fenomena ini sangat kuat terasa dalam tata hukum Indonesia yang berada dalam keluarga sistem civil law. Dapat ditebak bahwa fungsi hakim yang diposisikan seperti itu akan mudah mengarah pada menguatnya cara berpikir ala aliran legal positivism, dan ekstrimnya legisme. ${ }^{22}$

Agenda Hukum Progresif menawarkan paradigma baru dalam cara berhukum yang selama ini didominasi oleh paham hukum yang legal positivism. Lahirnya hukum progresif di

\footnotetext{
$21 \quad$ Ibid.

22 lbid. hlm. 8.
} 
latarbelakangi oleh ketidakpuasaan kinerja penegakan hukum dalam setting Indonesia akhir abad ke-20, berupa keprihatinan atas kualitas penegakan hukum di Indonesia. Dalam konteks Indonesia, pentingnya hukum progresif didasarkan pada pengalaman antara lain gagalnya hukum membawa koruptor ke penjara oleh penegak hukum (hakim). Kegagalan itu disebabkan oleh sifat submisif terhadap kelengkapan hukum yang ada, seperti prosedur, doktrin dan asas. Akibatnya hukum justru menjadi safe heaven bagi para koruptor. Dilihat dari sudut hukum Progresif, maka cara-cara dan praktek berhukum seperti itu sudah tergolong kontraprogresif. ${ }^{23}$

Hukum progresif menawarkan bentuk pemikiran dan penegakan hukum yang tidak submisif (tunduk sepenuhnya) terhadap sistem yang ada, tetapi lebih afirmatif. Afirmatif artinya memerlukan keberanian untuk melakukan pembebasan dari praktik konvensional dan menegaskan penggunaan cara yang lain. Langkah afirmatif tersebut akan menimbulkan terobosan-terobosan atau sering disebut rulebreaking. Hukum progresif mengajukan maksim, "hukum untuk manusia atau rakyat dan bukan sebaliknya". Ini dapat diperluas menjadi asas dan doktrin untuk rakyat bukan sebaliknya. Dengan paradigma ini, maka apabila rakyat menghadapi atau didera oleh suatu persoalan, maka bukan rakyat yang disalahkan, melainkan harus dicari jalan keluarnya atas hukum yang ada, termasuk meninjau asas, doktrin, subtansi, serta prosedur yang berlaku. ${ }^{24}$

Penataan ulang yang ditawarkan hukum progresif tentunya membutuhkan sebuah model atau kerangka kerja yang dapat memandu untuk menjalankan hukum progresif tersebut. Tanpa panduan atau model yang jelas yang berfungsi sebagai platform sulit kekuatan hu-

23 Satjipto Rahardjo. "Hukum Progresif sebagai Dasar Pembangunan Ilmu Hukum Indonesia". Dalam Buku: Menggagas Hukum Progressif Indonesia, Penyunting: Ahmad Gunawan dan Muammar Ramadhan, Yogyakarta: Pustaka Pelajar, hlm. 2-3.

24 Satjipto Rahardjo, 2009. op.cit. hlm. 141-142. Lihat dan bandingkan dengan Theresia Anita Christiani, "Studi Hukum Berdasarkan Perkembangan Paradigma Pemikiran Hukum Menujur Metode Holistik", Jurnal Hukum Pro Justitia, Vol. 26 No. 4 Oktober 2008, hlm. 347-358. kum progresif disatukan dalam satu komitmen. Tanpa kesatuan komitmen, langkah pembaruan yang terarah sulit diwujudkan, bahkan tidak mustahil, inisiatif individual seorang pelaku hukum dapat menjadi liar dan sewenang-wenang. L. Tanya mengajukan tiga pertimbangan pemikiran, pertama, bahwa hukum progresif berusaha menolak keadaan status quo, manakala keadaan tersebut menimbulkan dekadensi, suasana korup, dan semangat merugikan kepentingan rakyat; kedua, dalam hukum progresif melekat semangat perlawanan dan pemberontakan untuk mengakhiri kelumpuhan hukum melalui aksi kreatif dan inovatif para pelaku (aktor) hukum; dan ketiga, hukum progresif membutuhkan kehadiran sebuah exemplar atau contoh/model, yang akan dapat menyatukan kekuatan-kekuatan hukum progresif pada suatu platform aksi. Exemplar itu menyediakan tiga perangkat lunak yang dibutuhkan sebuah gerakan, yakni pertama, landasan ideologis yang mendasari gerakan yang diperjuangkan; kedua, masalah yang dianggap relevan dan penting untuk diperjuangkan dan dikerjakan; dan ketiga, Metode atau prosedur yang tepat dan efektif untuk menyelesaikan masalah dimaksud. Kejelasan tiga hal tersebut, per-teori, akan merekatkan kekuatan-kekuatan potensial hukum progresif dalam satu agenda dan garis perjuangan. Dengan begitu harapan bersatunya kekuatan hukum progresif seperti diserukan Rahardjo lebih mudah terwujud. ${ }^{25}$

Di antara sekian model yang ada, Interessenjurisprudenz merupakan satu model yang nampak lebih sesuai dengan semangat hukum progresif. Searah dengan hukum progresif aliran ini menganut prinsip melayani kepentingan dan memenuhi kebutuhan manusia merupakan tujuan utama dari hukum. Upaya mencapai tujuan tersebut tidak bisa hanya dengan mengandalkan penerapan aturan hukum secara hitam-putih. ${ }^{26}$

25 Bernard L. Tanya, 2005, Hukum, Politik dan KKN. Surabaya: Srikandi. hlm. 39. Baca pula Satj ipto Rahardjo, "Bersatulah Hukum Progresif", Kompas, 6 September 2004. Lihat pula Yohanes Suhardin, "Paradigma Rule Breaking dalam Penegakan Hukum yang Berkeadilan", J urnal Hukum Pro J ustitia, Vol. 26 No. 3 J uli 2008, hlm. 282-291.

26 Ibid. 
Kepentingan-kepentingan manusia sangat beragam, dan biasanya unik menurut ruang dan waktu. Oleh karena itu aparat penegak hukum dituntut untuk sedapat mungkin mengambil posisi seakan-akan ia mengalami sendiri kasus yang sedang ditangani. Inilah yang oleh Aristoteles disebut apiekeia. Dengan cara ini keadilan bisa ditemukan, sebab harus diakui bahwa keadilan tidak bisa secara langsung ditemukan lewat proses logis-formal. Keadilan justru diperoleh lewat intuisi. ${ }^{27}$

Aliran yang muncul di Jerman sekitar dekade awal Abad ke-20 itu, mengandalkan pemeriksaan yang cermat dan serius atas kepentingan-kepentingan yang dipertaruhkan dalam suatu kasus konkrit, berikut konteksnya yang relevan. Kemudian dengan menimbang dan menyelami bobot dari kepentingan-kepentingan yang dipertaruhkan itu, diambilah keputusan yang mendukung kepentingan yang lebih utama. Interessenjurisprudenz tegas-tegas menolak pertimbangan yuridis yang legalistik yang dilakukan secara pasang-jarak (disinterestedness), detached dan in-abstracto. Aliran ini tidak memulai pemeriksaan dari bangunan peraturan secara hitam putih, melainkan dari kasus khusus di luar narasi tekstual aturan itu sendiri. Cara ini merupakan siasat untuk menutup keterbatasan aturan dan teks-teks hukum yang mungkin tidak mengatur secara eksplisit mengenai suatu persoalan. Di sini dipegang teguh prinsip "keadilan tidak bisa dikorbankan hanya lantaran keterbatasan norma dan teks-teks hukum yang ada". Karena itu argumen-argumen legal dicari sesudah keadilan ditemukan untuk membingkai secara yuridisformal keputusan yang diyakini adil tersebut. ${ }^{28}$

Dari uraian di atas dapat ditemukan tujuan dan semangat yang sama antara hukum progresif dengan interessenjurisprudenz, setidak-tidaknya dalam lima hal, yaitu pertama, semangat menempatkan kepentingan dan kebutuhan manusia/rakyat sebagai tujuan utama dari hukum; kedua, kehendak menyelenggarakan hukum secara kreatif; ketiga, pentingnya kepekaan, empati, serta dedikasi dalam pe-

\footnotetext{
27 Ibid.

28 Ibid.
}

nyelenggaraan/ penegakan hukum; keempat, kearifan manusia (aparat penegak hukum) menjadi kata kunci pencapaian keadilan; dan kelima, tidak anti peraturan, akan tetapi berusaha terus-menerus memberi makna baru dalam ruang dan waktu yang tepat. ${ }^{29}$

Selain memerlukan exemplar baru, hukum progresif juga membutuhkan pelaku-pelaku hukum yang arif dan kreatif untuk menggarapnya karena kunci perubahan terletak pada penafsiran kontekstual terhadap hukum. Hukum progresif seperti juga Interssenjurisprudenz, tidak sekali-kali menafikan peraturan yang ada sebagaimana dianjurkan aliran freirechtlehre. Meski begitu hukum progresif tidak seperti legisme yang mematok peraturan sebagai harga mati. Hukum progresif juga tidak seperti analytical jurisprudence yang hanya berkutat pada proses logis-formal. Hukum progresif merangkul baik peraturan maupun kenyataan/kebutuhan sosial sebagai dua hal yang harus dipertimbangkan dalam tiap keputusan. ${ }^{30}$

Memadukan peraturan dan kenyataan secara adil bukanlah pekerjaan yang mudah. Suatu kenyataan yang biasanya bersifat spesifik, tidak selalu bias dipasang secara tepat dalam bingkai suatu aturan yang biasanya sangat umum. Lagi pula kenyataan yang tersodor, acapkali bukanlah kenyataan hitam-putih. Tidak jarang dalam dunia riil, harus menghadapi kenyataan dan keadaan di mana pertimbanganpertimbangan benar-salah berdasarkan aturan hukum tidak selalu menolong. Kenyataan atau keadaan di mana keputusan harus diambil dengan amat memperhitungkan konteks yang ada. Begitu kompleknya kenyataan sehingga hampir mustahil memperoleh keputusan yang adil hanya dengan mengandalkan pertimbangan legalistik semata.

Oleh karena itu, kehadiran pelaku hukum yang arif dan kreatif, mutlak perlu untuk memandu penafsiran yang luas dan kreatif terhadap aturan-aturan yang demikian itu. Seorang pelaku hukum progresif berusaha mencari dan menemukan keadilan dalam batas dan di tengah keterbatasan kaidah-kaidah hukum yang

\footnotetext{
29 Ibid.

30 lbid.
} 
ada. Itu pula sebabnya, kecerdikan dan kearifan pelaku hukum menyelami roh sebuah peraturan, serta kemampuan menentukan secara tepat keutamaan suatu kepentingan/kebutuhan sosial yang harus dilayani oleh hukum, merupakan kekuatan kinci dari hukum progresif.

Oleh karena itu praktik hukum progresif lebih mengandalkan kebijaksanaan para pelaku hukum, yaitu hakim, polisi, jaksa, dan advokat dalam memaknai hukum kini dan di sini. Hakim, polisi, jaksa dan advokatlah yang progresiflah yang sebenarnya menjadi ujung tombak perjuangan hukum progresif. Untuk mewujudkan hukum mereka harus bertindak sebagai a creative lawyer. Dari merekalah diharapkan lahir keputusan yang berkualitas 'yurisprudensial' (keputusan bermutu yang layak menjadi rujukan) untuk memandu perubahan hukum secara progresif. Tanpa panduan itu hukum progresif akan sulit terwujud. Di tengah kebanyakan orang (termasuk aparat penegak hukum) dikuasai sikap pragmatis-naif, bisa saja kebebasan yang diberikan hukum progresif itu disalahgunakan untuk menabrak hukum itu sendiri demi sebuah kemungkaran.

Agenda paradigma Hukum progresif juga tidak dapat melepaskan diri dari "pabrik jurist". Lembaga pendidikan hukum sebagai pencetak ahli hukum menjadi institusi yang strategis dalam sosialisasi Hukum Progresif. Agenda yang cukup mendesak di ranah pendidikan tinggi hukum adalah dengan melakukan reformasi kurikulum di bidang hukum. Sebagaimana disebutkan di muka bahwa agenda paradigma utama hukum progresif adalah menempatkan manusia sebagai sentralitas utama dari seluruh perbincangan tentang hukum. Filosofi dan paradigma hukum progresif adalah "hukum untuk manusia". Dengan bingkai pemahaman yang demikian maka sesungguhnya kurikulum pendidikan tinggi hukum niscaya memperbincangkan manusia dan kemanusiaan sebagai wacana awal dalam hukum. Jadi urutanya, manusia dulu baru kemudian disusul dengan hukum dengan segala atribut dan permasalahnnya. ${ }^{31}$

Di situ bukan berarti setelah menuntaskan pembicaraan manusia kemudian ditutup untuk pindah ke pembicaraan tentang hukum. Tidak demikian. Perbincangan tentang hukum untuk tahap berikutnya tidak akan menutup pintu bagi isu manusia dan kemusiaan. Hukum progresif tidak membuat batas seperti itu. Masalah manusia dan kemanusiaan akan terus mengalir memasuki hukum. Maka menjadilah bahwa hukum itu bukan untuk dirinya sendiri, melainkan untuk mengabdi dan melestarikan manusia dengan segala perbincangan tentang kebenaran dan keadilan di dalamnya. Dengan kurikulum yang demikian maka akan menawarkan lulusan yang siap untuk menegakkan martabat manusia, menolong yang susah, bersemangat menyanyangi dan memberi garansi alumniya tidak akan pernah berkolaborasi dengan pelaku kejahatan untuk merekayasa hukum untuk alat kejahatan. ${ }^{32}$

Pada saat faktor manusia dan kemanusiaan menjadi pusat perbincangan hukum progresif, maka faktor etika dan moralitas dengan sendirinya akan ikut terseret masuk di dalamnya. Oleh karena itu hukum progresif tidak bisa lepas dari membicarakan keadilan, kebenaran, dan kemanusiaan. Jadi dengan tegas hukum progresif menolak pendapat yang memisahkan hukum dari faktor kemanusiaan dan moralitas. Di sinilah faktor pencerahan yang dilakukan oleh hukum progresif.

Bertolak dari pembahasan yang telah diuraikan di atas, dapat diperoleh skema tentang proses rekonstruksi pola pikir hakim berbasis hukum progresif sebagai nampak pada bagan di bawah ini.

\section{Penutup \\ Simpulan}

Konstruksi baru pola pikir hakim berbasis hukum progresif sangat dibutuhkan hakim dalam proses memutuskan perkara korupsi. Hal ini

\footnotetext{
31 Satjipto Rahardjo," Kemanusiaan, Hukum dan Teknokrasi", Makalah pada Program Doktor IImu Hukum Undip 2005.

32 Ibid.
} 
didasarkan pada pengalaman empirik penanganan kasus-kasus korupsi oleh hakim di pengadilan banyak mengalami kemerosotan dan kegagalan untuk menghadirkan hukum yang adil, bermanfaat dan melindungi kepentingan masyarakat. Pola pikir hakim yang bercorak positivistik perlu ditata ulang berdasarkan pola pikir baru yang progresif dalam menyelesaikan problem hukum yang muncul akhir-akhir ini yang semakin kompleks dan rumit, terutama dalam memecahkan masalah korupsi.

\section{Saran}

Pendidikan hakim di semua tingkatan dan lingkungan pengadilan perlu ditingkatkan agar hakim mampu memecahkan berbagai permasalahan hukum secara tepat, adil dan bijaksana. Muatan hukum progresif perlu dielaborasikan dalam pendidikan calon hakim agar prinsip-prinsip hukum progresif tersosialisasikan sejak awal kepada para calon hakim. Di sisi lain institusi pendidikan hukum terutama fakultas hukum, harus memasukkan materi dan muatan hukum progresif dalam kurikulum pendidikannya, sehingga nilai-nilai hukum progresif dapat tersosialisasi sejak dini terhadap mahasiswa.

\section{Daftar Pustaka}

Ananda, Suadamara. "Hukum dan Moralitas", J urnal Hukum Pro J ustitia. Vol. 24 No. 3 J uli 2006. Bandung: FH Unpar;

Christiani, Theresia Anita. "Studi Hukum Berdasarkan Perkembangan Paradigma Pemikiran Hukum Menujur Metode Holistik". J urnal Hukum Pro J ustitia. Vol. 26 No. 4 Oktober 2008. Bandung: FH Unpar;

Garner, Bryan A. 1999. Black' Law Dictionary. Edisi ke-7. ST.Paul Minn: West Group;

Gunawan, Ahmad dan Muammar Ramadhan (ed). Menggagas Hukum Progressif Indonesia. Yogyakarta: Pustaka Pelajar;

Heuken, Adolf. "Teladan Hakim yang Bijaksana, Tegas, dan Memperhatikan Situasi". J urnal Keadilan, Vol. 2 No. 1, Tahun 2002;

Indarti, Erlyn. "Legal Constructivism: Paradigma Baru Pendidikan Dalam Rangka Pembangunan Masyarakat Madani". MajaIah IImiah Masalah-Masalah Hukum. Vol. XXX, No. 3. J uli - September 2001;

2010. Diskresi dan Paradigma Sebuah Telaah Filsafat Hukum, Pidato Pengukuhan J abatan Guru Besar dalam Flsafat Hukum pada FH Undip. Semarang: Undip;

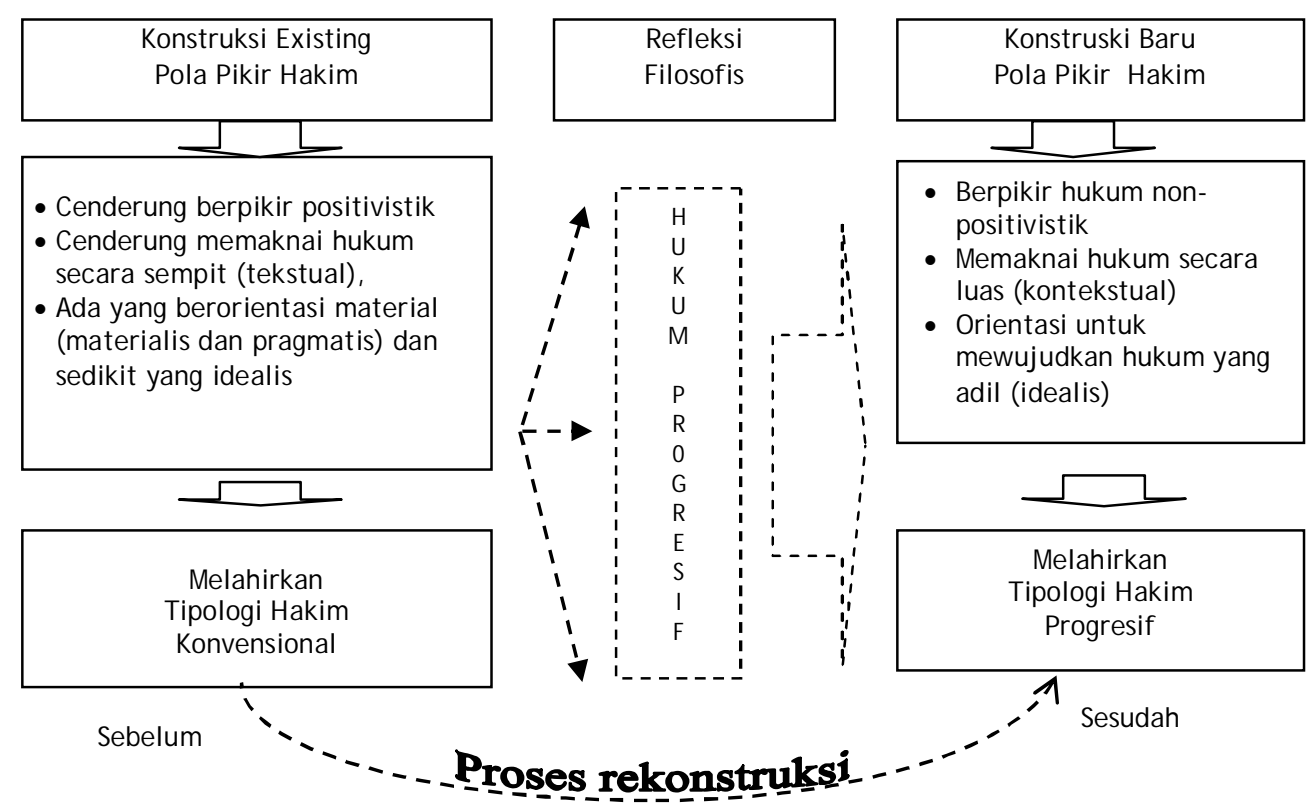

Bagan: Proses Rekonstruksi Pola Pikir Hakim Berbasis Hukum 
Irianto, Sulistyowati \& Shidarta (ed). 2009. Metode Penelitian Hukum Konstelasi dan Refleksi. Jakarta: Yayasan Obor Indonesia;

Koesnoe, Moh. "Apa Artinya Yuridis itu? Kajian Ukuran dan Persoalannya Dewasa ini". Varia Peradilan. No. 118 Edisi Juli 1995. J akarta: IKAHI;

Menski, Werner. 2006. Comparative Law in a Global Context, The Legal Systems of Asia and Africa. Second Edition. New York: Cambridge University Press;

Nitibaskara, Tb. Ronny R. "Hukum sebagai Alat Kejahatan". Kompas. 16 Oktober 2000;

Rahardjo, Satjipto. "Konstitusional dari Dua Sudut Pandang". Kompas. 7 September 1998;

"Bersatulah Hukum Progresif". Kompas, 6 September 2004;

"Hukum Progresif: Hukum Yang Membebaskan". J urnal Hukum Progresif Vol. 1 No. 1. April 2005;

" Kemanusiaan, Hukum dan Teknokrasi". Makalah pada Program Doktor IImu Hukum Undip 2005. Semarang: Undip;

2007. "Biarkan Hukum Mengalir Catatan Kritis tentang Pergulatan Manusia dan Hukum". J akarta: Kompas;

2009. Hukum Progresif sebuah Sintesa Hukum Indonesia. Yogyakarta: Genta Publishing;

------. 2009. Hukum Progresif sebuah Sintesa Hukum Indonesia. Yogyakarta: Genta Publishing;

Rani, Faisal A. "Hakim Sebagai "Quasi Legislator". Jurnal Hukum Pro Jusitia. Tahun Ke 20 No. 2. April 2002;

Ridwan. "Memunculkan Karakter Hukum Progresif dari Asas-asas Umum Pemerintahan yang Baik Solusi Pencarian dan penemuan Keadilan Substantif". J urnal Hukum Pro Justitia. Vol. 27 No. 1. April 2009. Bandung: FH Unpar;

Savitri, Niken. "Tugas Hakim dan Penafsiran Atas KUHP". J urnal Hukum Pro Jutitia. Vol. 25 No. 4 Oktober 2007. Bandung: FH Unpar;

SDW, Dodo. "Asas Negara Hukum Menurut Paham Pancasila". Jurnal Keadilan. Vol.
2 No. 1. Tahun 2002;

Shidarta. 2006. "Filosofi Penalaran Hukum Hakim Konstitusi dalam Masa Transisi Konstitusionalitas". J urnal Hukum J entera, Edisi 11-tahun III, J anuari-Maret 2006;

Sugito dkk. 2002. Pendidikan Pancasila. Semarang: UPT MKU UNNES;

Suhardin, Yohanes. "Paradigma Rule Breaking dalam Penegakan Hukum yang Berkeadilan". J urnal Hukum Pro Justitia. Vol. 26 No. 3 J uli 2008. Bandung: FH Unpar;

Suparlan, Parsudi. "Paradigma Naturalistik dalam Penelitian Pendidikan: Pendekatan Kualitatif dan Penggunaannya". Majalah Antropologi Indonesia. Vol. 21 No. 53. Tahun 1997. J akarta: FISIP UI;

Syamsudin, M. "Kecenderungan Paradigma Berpikir Hakim dalam Memutuskan Korupsi", J urnal Media Hukum. Vol.15 No.2. Des 2008 Yogyakarta: FH UMY;

"Pemaknaan Hakim tentang Korupsi dan Implikasinya terhadap Putusan: Studi Perspektif Hermeneutika Hukum". J urnal Mimbar Hukum. Vol. 22 No.4. Oktober 2010. Yogyakarta: FH UGM;

Tanya, Bernard L. 2005. Hukum, Politik dan KKN. Surabaya: Srikandi;

Warassih, Esmi. "Hukum Progresif Jawaban Alternatif Menuju Pembangunan Hukum Indonesia Menghadapi Mafia Peradilan". Makalah disampaikan pada Seminar Nasional Menembus Kebuntuan Legal Formal Menuju Pembangunan Hukum dengan Pendekatan Hukum progresif pada tanggal 19 Desember 2009. Semarang: FH Undip;

Wignyosoebroto, Soetandyo. 2010. "Mempersoalkan Keadilan dalam Amar Putusan Hakim dalam Wajah Hakim dalam Putusan, Studi atas Putusan Hakim Berdimensi Hak Asasi Manusia. Yogyakarta: PUSHAM UII;

Winata, Frans H. "Pencapaian Supremasi Hukum yang Beretika dan Bermoral". J urnal Hukum Pro Justitia. Tahun XX No. 1 Januari 2003. Bandung: FH Unpar;

Wisnubroto, Al. “Upaya Mengembalikan Kemandirian Hakim Melalui Pemahaman Realitas Sosialnya". J urnal Hukum Pro J ustitia. Tahun XX No. 1. Januari 2003. Bandung: FH Unpar. 